\title{
ELŐKEVERÉSES ÉGŐ SZÉN-MONOXID KIBOCSÁTÁSÁNAK CSÖKKENTÉSE DIFFÚZOROS ÉGŐSZÁJ KIALAKÍTÁSSAL
}

\section{CARBON MONOXIDE REDUCTION OF A LEAN PREMIXED PREVAPORISED BURNER USING DIFFUSERS}

\author{
Hidegh Gyöngyvér \\ Budapesti Müszaki és Gazdaságtudományi Egyetem, Gépészmérnöki kar, Energeti- \\ kai Gépek és Rendszerek Tanszék, Magyarország 1111 Budapest Müegyetem rakpart \\ 3.; +36305052111, Magyarország 1144 Budapest Csertő park 2. 6/61., \\ gyongyver.hidegh@gmail.com
}

\begin{abstract}
Nowadays pollutant emissions are getting more and more attention, therefore laws, regulations and standards restrict the maximum concentration of the pollutants in the flue gas. Broadening the range of the flame stability is highly important, since lower pollutant emissions can be reached in this way. A feasible solution for this is applying a diffuser on the burner lip. Measurements were carried out using the construction mentioned above, and the current paper examines the effect of the diffusers on the changes of the carbon monoxide emission.
\end{abstract}

Keywords: gas turbine, premixed prevaporized burner, diffuser, CO emission

\section{Összefoglalás}

Napjainkban a károsanyag kibocsátás egyre nagyobb figyelmet kap, így törvények, rendeletek és szabványok korlátozzák a károsanyagok maximális koncentrációját a füstgázban. A stabil égési tartomány szélesítése kiemelt jelentőségü, mivel ezzel még alacsonyabb kibocsátási értékek érhetők el. Erre egy lehetséges megoldás az égőszáj megtoldása diffúzoros kialakítású elemmel. Kutatásom során labormérések segítségével ilyen konstrukciók hatását vizsgálom a szén-monoxid kibocsátás változására.

Kulcsszavak: gázturbina, elökeveréses égö, diffúzor, CO kibocsátás

\section{Bevezetés}

A tüzelési folyamatokból eredő szénmonoxid kibocsátás az utóbbi évtizedekben nagy figyelemre tett szert az egészségre és a környezetre gyakorolt káros hatásának köszönhetően [1]. A szén-monoxid belélegezve csökkenti a vér oxigénfelvevő képességét, és magas koncentráció esetén akár halált okozhat [2].

Megfelelö égőkialakítással széles üzemi tartományon müködtethető berendezés hozható létre. Korábbi megfigyelések alapján
[3][4][5] erre egy jó módszer lehet a diffúzoros égőszáj kialakítás alkalmazása. A gyakorlati megvalósíthatósághoz viszont elengedhetetlen a konstrukció vizsgálata többek között a szén-monoxid kibocsátás szempontjából.

\section{Mérőrendszer bemutatása}

A 2.1. ábrán látható tesztpadon az égéslevegő térfogatáramok beállítását egy frekvenciaváltó tette lehetővé.

A 2.2. ábrán látható a mérőberendezés tüzelöanyag rendszer része 


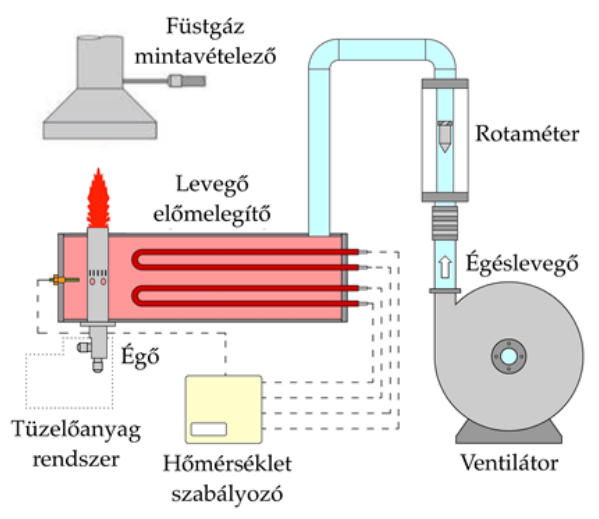

2.1. ábra. Égéslevegö rendszer [6]

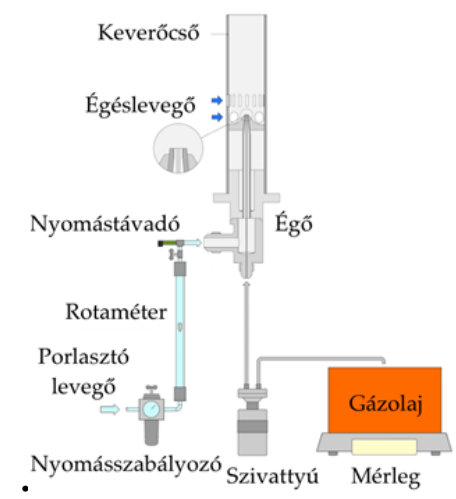

2.2. ábra. Tüzelöanyag rendszer [6]

A különböző félkúpszögü diffúzoros toldatok azonos méretü hengerekből lettek kimunkálva, így a többlet anyag lehütheti a lángot. Részben emiatt terjedt ki a mérés a $0^{\circ}$-os félkúpszögü elemre is, ami gyakorlatilag a keverőcső megtoldását jelentette mintegy 21\%-kal. A vizsgált konfigurációk metszetét a 2.3. ábra szemlélteti. Az alkotó minden esetben $16 \mathrm{~mm}$ volt. Az elemeket a $30 \mathrm{~mm}$ külső átmérőjü égő szájára illesztettük a megvezetés segítségével. Nyílásszög tekintetében a $0^{\circ}-60^{\circ}$-ig terjedő sorozatot hasonlítottam össze az eredeti konfiguráció tulajdonságaival, $15^{\circ}$-os lépésközzel. A méréseket a következőképpen végeztük: adott tüzelőanyag tömegáram és fúvóka konstrukció mellett állandó porlasztó- nyomáson, egyenlö lépésközönként fokozatosan növeltük az égéslevegő mennyiségét $12 \mathrm{~kg} / \mathrm{h}$-tól a láng lefúvásáig.

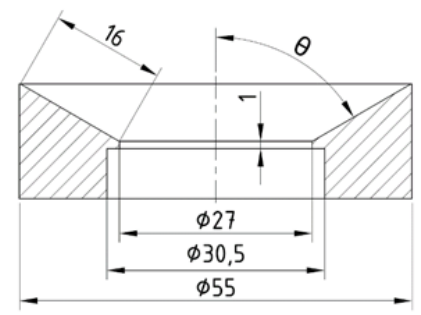

2.3. ábra. A diffúzorok metszete

\section{Eredmények, következtetések}

A kibocsátási értékek érdemleges öszszehasonlíthatósága kedvéért a jelenleg Magyarországon érvényben lévő, KöM 7/1999 VII. 21-es rendelet szerint végeztem a kiértékelés. A $140 \mathrm{~kW}$-nál nagyobb tüzelési teljesítményü gázturbinákra 15\%-os oxigénszint mellett a megengedett maximális kibocsátás $100 \mathrm{mg} / \mathrm{m}^{3}$ (80 ppm) CO. A különböző konstrukciók esetében a korrigált kibocsátási értékek rendre a 3.1. ábrán láthatók, melyeken a feltüntetett értékek mellett azok színezése is jellegre jól mutatja a kibocsátás változását. Megállapítható, hogy a sötétebb zöld tartományokban a $\mathrm{CO}$ kibocsátás a határérték alatt marad.

$\mathrm{Az}$ egyes ábrákon látható károsanyag kibocsátási térképek alakja jól mutatja a különböző konstrukciós megoldások segítségével létrejövő lángstabilitási tartomány változását. Megfigyelhető, hogy a 3.1.c és a 3.1.d ábrákon a mérhető tartomány jóval nagyobb területet fedne le a légfeleslegtényező-porlasztónyomás síkon, mint a többi esetben. Korábbi tapasztalatok alapján [3], [4], [5] ezen konstrukciók esetében a láng nagyobb légfeleslegtényező értékekig $(\lambda \simeq 2,2)$ is képes stabil maradni, viszont jelen esetben miután a mért $\mathrm{CO}$ mennyisége meglehetősen átlépte a megengedett határértéket, már nem folytattuk tovább a méréseket. 

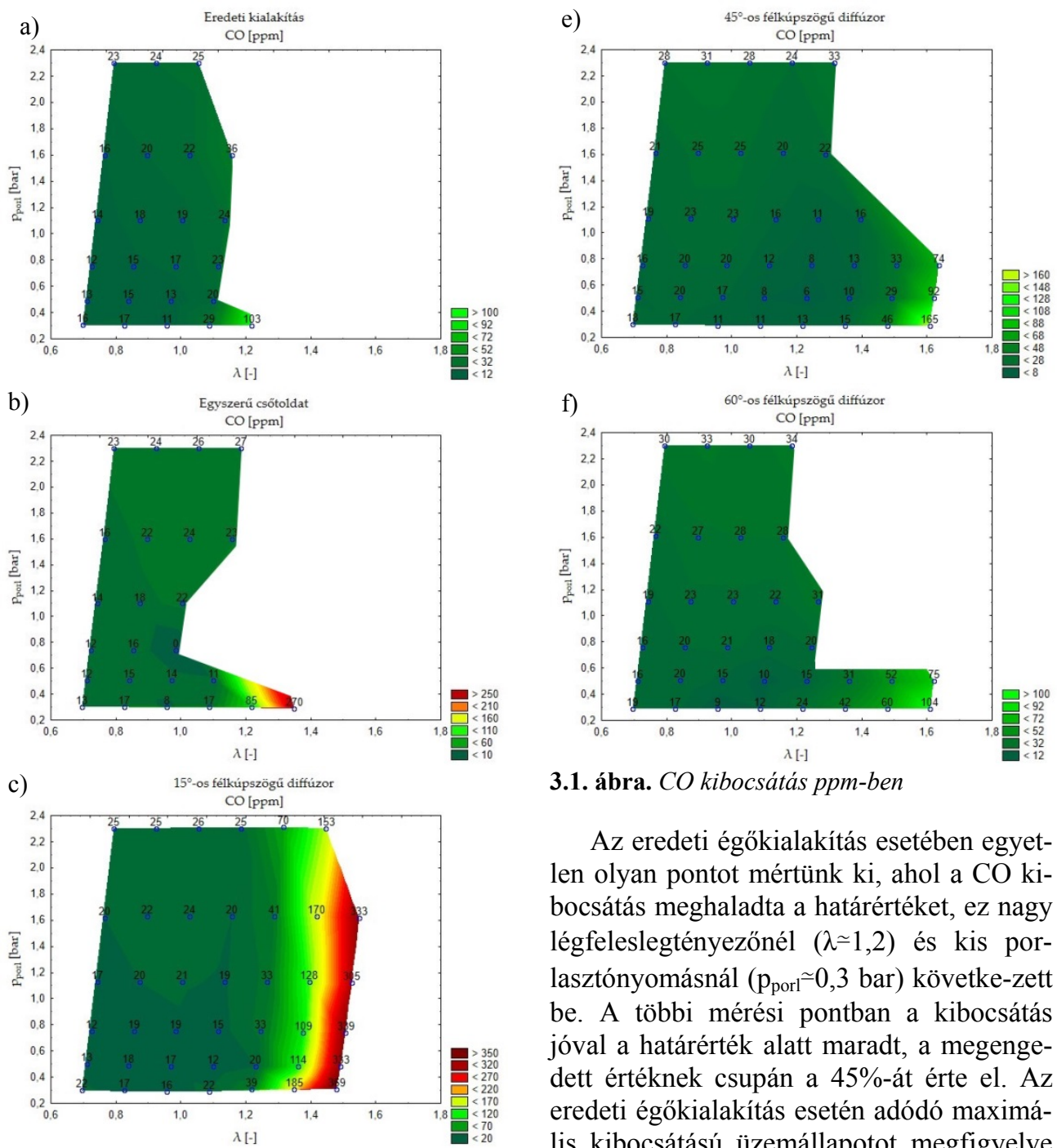

3.1. ábra. CO kibocsátás ppm-ben

Az eredeti égőkialakítás esetében egyetlen olyan pontot mértünk ki, ahol a CO kibocsátás meghaladta a határértéket, ez nagy légfeleslegtényezőnél $(\lambda \simeq 1,2)$ és kis porlasztónyomásnál ( $\mathrm{p}_{\mathrm{porl}} \simeq 0,3$ bar) követke-zett be. A többi mérési pontban a kibocsátás jóval a határérték alatt maradt, a megengedett értéknek csupán a 45\%-át érte el. Az eredeti égőkialakítás esetén adódó maximális kibocsátású üzemállapotot megfigyelve látható, hogy az alkalmazott konstrukciós módosítások eredménye-képpen a mért kibocsátás akár egy nagyságrenddel kisebb lesz. Például a $45^{\circ}$-os félkúpszögü diffúzor esetében ennek a kibocsátásnak csak a $13 \%$-át mértük.

Az egyszerü csőtoldat esetében kis porlasztónyomáson hiába volt szélesebb tartományban stabil a láng, a mért határon már 337\%-os a CO kibocsátás a megengedetthez képest. A 3.1.b ábrán látható egy mi- 
nimum hely, ahol nem mértünk CO kibocsátást: a $\lambda \simeq 1$ és a $\mathrm{p}_{\mathrm{porl}} \simeq 0,7$ bar pontban. Ehhez hasonlóan a 3.1.c, $\mathbf{d}$, $\mathbf{e}$ és f ábrákon is megfigyelhetö egy minimum érték a kibocsátási térképeken, a $\lambda \simeq 1$ és $p_{\text {porl }} \simeq 0,5$ bar pont körül.

A $15^{\circ}$-os és a $30^{\circ}$-os félkúpszögü diffúzor esetében a térképek színezettsége alapján hasonlóan változik a paraméterek függvényében a $\mathrm{CO}$ kibocsátás. Bizonyos légfeleslegtényező értékig $(\lambda \approx 1,3)$ nem látható mérvadó változás a kibocsátásban, míg $\lambda \simeq 1,3$ fölött nagymértékủ növekedés tapasztalható. Kiváltképp a 3.1.c ábra esetében figyelhető meg, hogy a nagyobb légfeleslegtényező értékeknél a kibocsátási térképen a szintvonalak a függőlegeshez közelítenek. Következtetés képpen ebben a tartományban a CO kibocsátás jóformán csak a légfeleslegtényezőtől függ, a porlasztónyomástól független. Mivel ebben a tartományban a kibocsátás messze meghaladja az elöírt maximumot, egy adott müködtetni kívánt berendezésben ezen kedvező tulajdonságot nem lehet kihasználni, hiszen ebben a tartományban a konstrukció nem alkalmazható.

A $45^{\circ}$-os és a $60^{\circ}$-os félkúpszögü diffúzor esetében csak igen magas légfeleslegtényező értéknél megy a CO kibocsátás a megengedett fölé. Elsősorban a $45^{\circ}$-os félkúpszögủ megoldás lehet a legkedvezőbb, hiszen itt szélesebb tartományon mértünk alacsony $\mathrm{CO}$ kibocsátást.

A határérték alatti tartományokban minden konstrukció esetében megállapít-ható, hogy adott légfeleslegtényező mellett a porlasztónyomás növelésével nő a CO kibocsátás (eltekintve a korábban bemutatott minimum helyektöl). A határérték felett a kibocsátás fordított karakterisztikát mutat, azaz adott légfeleslegtényező mellett a porlasztónyomás növelésével csökken a CO kibocsátás.

\section{4. Összefoglalás, további tervek}

A CO kibocsátásról általánosságban megállapítható, hogy a légfelesleg növelésével egyre nagyobb mértékü, és a porlasztónyomástól csak kis mértékben függ. A lángstabilitás szempontjából igen kedvező tulajdonságokat mutató $15^{\circ}$-os és $30^{\circ}$-os félkúpszögü diffúzor esetében magas légfelesleg esetén, tehát az üzemi tartomány szélén már messze nem megengedhető a $\mathrm{CO}$ kibocsátás, így ebben a tartományban ez a két konstrukció a gyakorlatban nem alkalmazható. A $45^{\circ}$-os és $60^{\circ}$-os félkúpszögü kialakítások az eredeti konstrukcióhoz képest szélesebb üzemi tartománnyal rendelkeztek, és a mért CO kibocsátás csak néhány pontban, magas légfeleslegtényező értékeknél haladta meg a megengedhetöt, egyébként széles tartományban messze az alatt maradt.

A későbbiekben hasznos lenne a további károsanyag összetevők változását is mérni.

\section{Szakirodalmi hivatkozások}

[1] A. H. Lefebvre, D. R. Ballal: Gas Turbine Combustion Alternative Fuels and Emissions, 3. CRC Press Taylor \& Francis Group, 2010.

[2] E. Seaton, A., MacNee, W., Donaldson, K., Godden: Particulate Air Pollution and Acute Health Effects, Lancet, vol. 345, pp. 176-8, 1995.

[3] Gy. Hidegh: Elökeveréses égö stabilitási és spektrometriai vizsgálata, in Budapesti Műszaki és Gazdaságtudományi Egyetem, Tudományos Diákköri Konferencia, Energetika 1 szekció, 2015.

[4] Gy. Hidegh, V. Józsa: Diffúzor alkalmazása perdületes égö lánglefúvási stabilitásának növelésére, Energiagaz-dálkodás, vol. 3-4, pp. 17-20, 2016.

[5] A. Kun-Balog, V. Józsa: Spectroscopic analysis of crude rapeseed oil flame, Fuel Process. Technol., vol. 139, pp. 61-66, 2015.

[6] A. Kun-Balog, V. Józsa, K. Sztankó: Pollutant emission analysis of aqueous bioethanol combustion, Proc. 11th Conf. Sustain. Dev. Energy, Water Environ. Syst., no. SDEWES2016.0369, p. 8, 2016. 